\title{
Sore Throat in Children: Its Causation and Incidence*
}

\author{
P. W. ROSS, S. M. K. CHISTY, J. D. E. KNOX
}

\section{Summary}

Beta-haemolytic streptococci were isolated from $35 \%$ of 525 children who presented to their family doctors with sore throat. The first 306 were investigated bacteriologically and virologically and beta-haemolytic streptococci were isolated from $30 \%$ and viruses from $14.7 \%$. The ages which had the highest incidence of sore throat, for both sexes, were 7 , then 6,8 , and 5 . Those with tonsils had a higher incidence of beta-haemolytic streptococci than those without, but the presence or absence of tonsils made no difference to the degree of growth of the streptococci.

Viruses were isolated predominantly during the winter months, but streptococci, though mostly isolated in winter, were isolated throughout the rest of the year.

\section{Introduction}

In previous years several studies on throat infections, especially streptococcal, covering a wide geographical area and ranging widely in the categories of persons surveyed, have been conducted. Some dealt with people living in entirely open communities (Landsman et al., 1951; Breese and Disney, 1956; Esmann, 1959; Siegel et al., 1961; Glezen et al., 1967) whereas others concentrated either on semiclosed communities such as the armed Services (Commission on Acute Respiratory Diseases, 1944, 1945, 1947; Coburn and Young, 1949; Rammelkamp et al., 1952; Brumfitt et al., 1959) or on closed communities (Bishop et al., 1952; Holmes and Williams, 1958; Zanen et al., 1959; Moffett et al., 1964). In some of these studies adults were investigated (Rammelkamp et al., 1952), in others children (Holmes and Williams, 1958), and in others both adults and children (Landsman et al., 1951; Zanen et al., 1959).

At the present time, however, there is little information on the current role of beta-haemolytic streptococci, and especially the different serotypes of Streptococcus pyogenes, in the causation of sore throat. In order to investigate this a prospective study was conducted on children living in an urban community in Scotland. In addition to studies on beta-haemolytic streptococci, the incidence of viruses in cases of sore throat was also investigated. The present paper reports the findings of the study.

\section{Materials and Methods}

The Population.-The study was conducted in a large National Health Service group practice in a semi-industrial area of Edinburgh, where, though all social and economic groups were represented, most patients belonged to the Registrar General's social groups III, IV, and V. The practice was conducted from two main premises, surgery $M$ serving a population of about 14,000 patients and surgery $C$ about 7,000 . The study was concerned with that part of the practice attending at surgery $M$.

*Based on part of theses accepted for the degrees of M.D. University of Aberdeen and Ph.D. University of Edinburgh.

\footnotetext{
Department of Bacteriology, University of Edinburgh, Edinburgh EH8 9AG

P. W. ROSS, M.D., M.I.BIOL., Lecturer

Department of Microbiology, University of Karachi

S. M. K. CHISTY, PH.D., DIP.BACT., Lecturer

Department of General Practice, University of Dundee

J. D. E. KNOX, M.D., F.R.C.P.ED., Professor
}

There was an annual turnover of about $10 \%$ in the practice population.

Selection of Patients.-Children between the ages of 3 and 15 years who consulted their doctor because of sore throat or any of the symptoms and signs associated with streptococcal or viral throat infection (dysphagia, tonsillar exudate, cervical adenopathy, pyrexia (over $99^{\circ} \mathrm{F} ; 37 \cdot 2^{\circ} \mathrm{C}$ ), vomiting, diarrhoea, conjunctivitis) were admitted to the study. These symptoms and signs were tabulated on a form on which was included information about the patient's presenting complaint, duration of illness before consulting the doctor, and attempts at home treatment. The doctor swabbed the anterior nares of the child, took two throat swabs-one for bacteriological and the other for virological examinations-and completed a form for each child.

The study lasted for 31 months in 1966-8. It was discontinued during July 1966 and July 1967 because of vacation arrangements. A total of 525 index cases comprising 474 children were examined and recorded; 427 of these had one episode, 43 had two episodes, and 4 suffered three episodes of sore throac.

About one-third of the patients in the practice were aged 15 years or less, with an equal distribution between the sexes.

\section{LABORATORY METHODS}

Bacteriology Studies.-Throat swabs were examined in the University Department of Bacteriology. Two plates, of $5 \%$ blood agar, were inoculated with each swab and incubated at $37^{\circ} \mathrm{C}$ for 14 to 18 hours. The blood agar plate was incubated aerobically and the other, which also contained 1:500,000 crystal violet, was incubated anaerobically. Sheep blood was substituted for horse blood midway through the study because of its effectiveness in preventing the growth of haemolytic haemophili.

Beta-haemolytic streptococci were screened by the bacitracin disc method (Maxted, 1953) and those which were resistant to bacitracin were grouped by the precipitin method (Lancefield, 1933). Group A strains were typed by the slide agglutination method (Griffith, 1934) utilizing T-antisera (Williams, 1958). Strains which could not be typed by the T-agglutination method were dispatched to the Streptococcus Reference Laboratory, Colindale, where $\mathrm{T}$-agglutination and $\mathrm{M}$-precipitation methods (Swift et al., 1943) were used in their examination.

Virology Studies.-The throat swab was broken into a bijou bottle containing $4 \mathrm{ml}$ of transport medium (1\% bovine serum albumin in medium 199 and $5 \%$ of $4.4 \%$ sodium bicarbonate) and was sent to the laboratory in a vacuum flask packed with ice. On reaching the laboratory 300 units of penicillin, $300 \mu \mathrm{g}$ of streptomycin, and 150 units of nystatin (Nystan) suspended in $0.1 \mathrm{ml}$ of phosphate-buffered saline were added to the specimen, which was stored at $-70^{\circ} \mathrm{C}$ until tissue cultures became available. Specimens were inoculated into two tissue culture tubes each containing HEp2 cells, secondary monkey kidney cells, and human embryo lung cells. Each culture, which was rolled at $34^{\circ} \mathrm{C}$, was examined on alternate days for any cytopathogenic effect and was changed on the fifth day. On the tenth day the cultures were frozen, thawed, and a blind passage was made into new cultures. In the identification of virus isolates haemadsorption inhibition tests (Grist et al., 1966) and tube neutralization tests (Vogel and Shelokov, 1957) were used.

\section{Results}

A total of 525 cases were examined and documented. Bacteriological and virological studies were conducted on the first 306 but the remainder were examined bacteriologically only. More 
males than females had sore throats in the youngest age groups. Those aged 3 and 4 had a low incidence whereas the ages of highest incidence for boys were $5,4,7$, and 8 years and for girls 6 and 7 years. The age of highest incidence for both sexes was 7 , closely followed by 6,8 , and 5 years.

Fig. 1 shows the distribution of sore throat by aetiology and by season. Though from January to March 1966 the proportion of streptococcal and viral isolations was reasonably similar, the streptococcal fraction was greater than the viral from April onwards. A notable feature seen in Fig. 1 is the large number of cases from whose throats no infective agent was isolated. Indeed this group accounted for more than half the cases in most periods. Infective agents were isolated from $\mathbf{4 4 . 7 \%}$ of the first 306 cases, beta-haemolytic streptococci accounting for $30 \%$ and viruses for $14.7 \%$. Of all 525 cases investigated bacteriologically, betahaemolytic streptococci were isolated from $35 \%$.

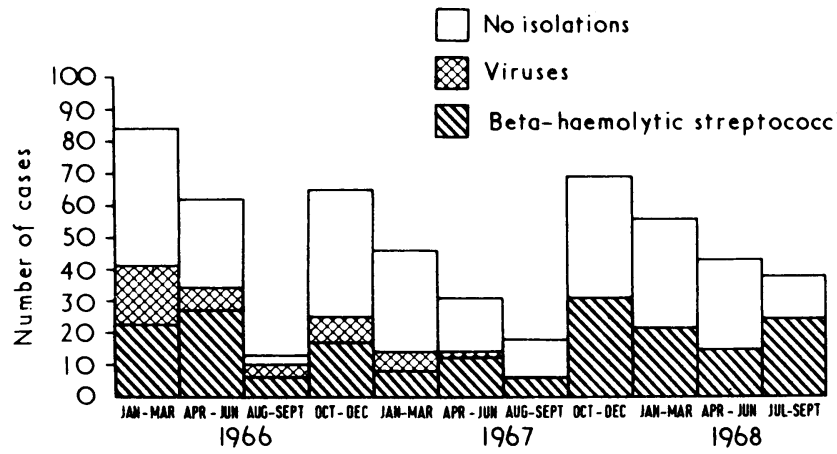

FIG. 1-Incidence of sore throat and number of isolations of beta-haemolytic streptococci and viruses from index cases by season.

The isolation rate for viruses was as follows: rhinovirus $1.6 \%$; influenza $B$ virus $3.3 \%$; parainfluenza virus $1.9 \%$; adenovirus $0.7 \%$; Herpesvirus hominis $4.9 \%$; enterovirus $2.3 \%$.

The seasonal incidence of streptococcal isolations did not pursue any definite pattern; the peak in 1966 was April-June, in 1967 October-December, and in $1968 \mathrm{July}$-September. The isolation rate for all viruses except enterovirus was significantly higher in the winter than in the summer months.

Four hundred and thirty-two children $(82.3 \%$ ) had tonsils. Information on 25 was not available because of their having left the district. A higher incidence of isolations of betahaemolytic streptococci was obtained from those with tonsils than those without (Table I). It was thought that the degree of growth of streptococci isolated from cases with tonsils in situ might be greater than from those without, but Table II shows

TABLE I-Percentage Isolation of Beta-haemolytic Streptococci from Index Cases with and without Tonsils

\begin{tabular}{|c|c|c|c|c|c|c|}
\hline & & \multirow{3}{*}{$\begin{array}{l}\text { Total } \\
\text { No. }\end{array}$} & \multicolumn{4}{|c|}{ Beta-haemolytic Streptococci } \\
\hline & & & \multicolumn{2}{|c|}{ Present } & \multicolumn{2}{|c|}{ Absent } \\
\hline & & & No. & $\%$ & No. & $\%$ \\
\hline $\begin{array}{l}\text { With tonsils } \\
\text { Without tonsils }\end{array}$ & $\begin{array}{l}. \\
\cdots\end{array}$ & $\begin{array}{r}432 \\
68\end{array}$ & $\begin{array}{r}175 \\
17\end{array}$ & $\begin{array}{l}40 \cdot 5 \\
25\end{array}$ & $\begin{array}{r}257 \\
51\end{array}$ & $\begin{array}{l}59 \cdot 5 \\
75\end{array}$ \\
\hline
\end{tabular}

TABLE II-Effect of the Presence and Absence of Tonsils on the Degree of Growth of Beta-haemolytic Streptococci

\begin{tabular}{|c|c|c|c|c|c|c|c|}
\hline & \multirow{2}{*}{$\begin{array}{l}\text { Total } \\
\text { No. }\end{array}$} & \multicolumn{2}{|c|}{$\dagger+\dagger$} & \multicolumn{2}{|c|}{$\dagger+$} & \multicolumn{2}{|c|}{$t$} \\
\hline & & No. & $\%$ & No. & $\%$ & No. & $\%$ \\
\hline $\begin{array}{l}\text { All beta-haemolytic } \\
\text { streptococci } \\
\text { Tonsils present } \\
\text { Tonsils absent }\end{array}$ & $\begin{array}{r}192 \\
175 \\
17\end{array}$ & $\begin{array}{r}88 \\
82 \\
6\end{array}$ & $\begin{array}{l}45.8 \\
46.8 \\
35.3\end{array}$ & $\begin{array}{l}91 \\
81 \\
10\end{array}$ & $\begin{array}{l}47 \cdot 4 \\
46 \cdot 7 \\
58 \cdot 8\end{array}$ & $\begin{array}{r}13 \\
12 \\
1\end{array}$ & $\begin{array}{l}6.8 \\
6.5 \\
5.9\end{array}$ \\
\hline
\end{tabular}

$++\dagger=$ More than 50 colonies per plate

$+t^{+}=$Between 20 and 50 colonies per plate that this was not so. No significant difference exists between the categories of degree of growth in those with tonsils and those without $\left(x^{2}=0483 ; P=0.5\right)$.

One hundred and eighty seven strains of beta-haemolytic streptococci belonged to Lancefield's group A, and Fig. 2 shows the breakdown into individual serotypes and complexes of serotypes. Ten different types were identified as well as representatives of the three main complexes, within which crossreactions are common. Patterns of these cross-reactions are shown in Fig. 3. Individual types 3, 5, 8, 11, 12, IMP 19, 25, and 44 as well as combinations of two or more were identified.

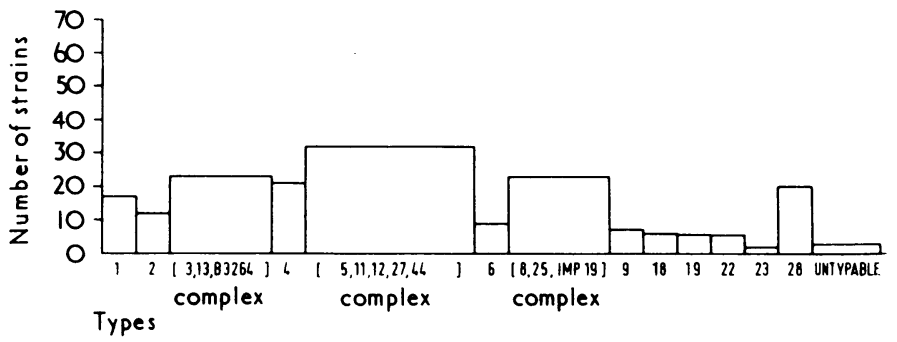

FIG. 2-Distribution of serotypes of 187 strains of Str. pyogenes.

No association was found between the isolation of certain types of beta-haemolytic streptococci and seasonal incidence, nor were any types predominantly associated with any particular age or sex.

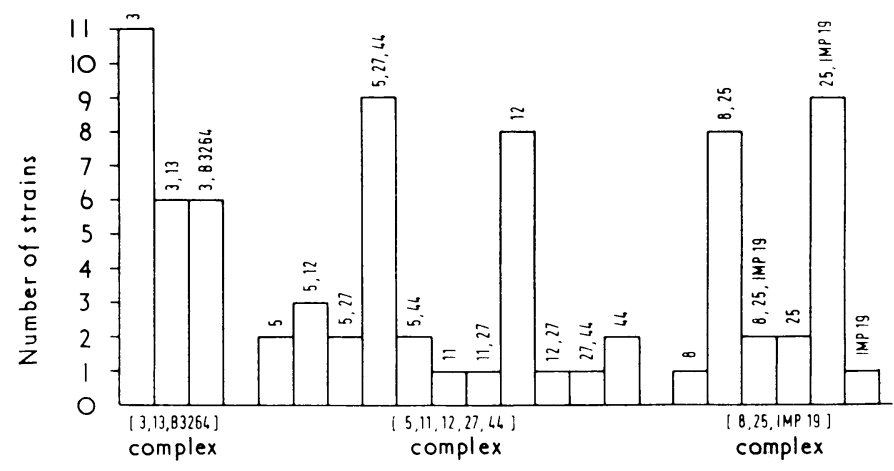

FIG. 3-T-agglutination patterns in cross-reaction complexes.

With the assistance of the Streptococcus Reference Laboratory, $98.4 \%$ of the 187 strains were typed.

\section{Discussion}

Preschool children had a lower incidence of streptococcal sore throat than schoolchildren, the ages of highest incidence for both sexes being 7 , then 6,8 , and 5 years. Other workers (Holmes and Williams, 1954; Brimblecombe et al., 1958) have also described a lower incidence of sore throat in preschool children. Varying seasonal patterns have been described. Coburn and Pauli (1941) reported a rising incidence in the first quarter of the year and a peak in the second, Dingle et al. (1953) described September-April as the period of highest incidence and Cornfeld et al. (1958) February-April. Neither Masters et al. (1958) nor Homes and Williams (1958) reported significant seasonal trends. In the present study sore throats occurred more often in the winter than in the summer months, but though the incidence of sore throats of viral origin and sore throats from which no isolations were made followed this pattern quite closely, this was not so with the streptococcal sore throats. In general, however, the report of a higher incidence of streptococcal sore throats in winter than in summer (Boycott, 1966) is supported. 
Beta-haemolytic streptococci were isolated from $35 \%$ of the 525 cases. In studies conducted by the Commission on Acute Respiratory Diseases (1944) these were isolated from only $25 \%$ of all cases and in the investigations of Bishop et al. (1952) the yield of these organisms was $43 \%$ from 115 cases of sore throat. Evans and Dick (1964) reported an isolation rate of only $26.3 \%$ though they isolated an identifiable micro-organism from $64.1 \%$ of persons studied compared with an isolation rate of $44.7 \%$ in the present study.

In the study of Higgins et al. (1965), in which there were similarities to the present one in technique and in the population studied, the isolation rate for viruses was $24.8 \%$, which was higher than that of the present study. Respiratory syncytial virus was isolated in their study but not in the present one and this accounts for part of the difference. Banatvala et al. (1965) reported a virus isolation rate of $28.2 \%$ but this included two epidemics, one caused by influenza and the other by parainfluenza viruses. In the report of the M.R.C. (1965), which included all respiratory infections, a virus isolation rate of $22.1 \%$ was obtained from cases of sore throat. Results of the present study compare with those of Glezen et al. (1967) whose virus isolation rate was $13 \cdot 6 \%$.

Though the isolation rate of beta-haemolytic streptococci was higher from those with tonsils than from those without, a fact which had been reported previously (Holmes and Williams, 1954, 1958; Brimblecombe et al., 1958; Mozziconacci et al., 1961), the degree of growth of these organisms on culture media was no greater from the cases with tonsils than from those without. Degree of growth of bacteria often indicates the severity of an infection, and it was thought therefore that children with tonsils might have a double liability, that of having a greater chance of carrying beta-haemolytic streptococci as well as having a greater chance of a more severe attack of sore throat. The latter hypothesis was not sustained however.

Lancefield's group A comprised $\mathbf{9 7 . 4} \%$ of the beta-haemolytic streptococci. In similar investigations by other workers the percentage of group A organisms was as follows: Bishop et al. (1952) $92 \%$; Valkenburg et al . (1963) $91 \%$; M.R.C. (1965) $90 \%$.

Of all the strains of Str. pyogenes, $98.4 \%$ were typable. This figure compares well with those of 12 other laboratories which participated in an international survey on the distribution of Str. pyogenes (Parker, 1967). Laboratories which gave comparable results were London $(95.7 \%)$, Prague $(97.9 \%)$, Copenhagen $(97 \cdot 3 \%)$, Jerusalem $(99 \cdot 8 \%)$, Atlanta $(97 \cdot 0 \%)$, and Moscow $(98.0 \%)$. Similar figures were also produced by Zanen et al. (1959), Mitchell (1962), and Higgins et al. (1965).

These results show that beta-haemolytic streptococci, and especially Str. pyogenes, still commonly cause sore throat in children, and swabs for bacteriological examination must be taken from every child presenting with sore throat so that appropriate therapy may be given.

We are greatly indebted to Professor Robert Cruickshank for his help in planning and organizing the research programme and for his interest and advice. Thanks are also due to Dr. M. T. Parker and Dr. W. R. Maxted for giving invaluable help as well as providing sera. We are deeply grateful to them and to the staff of the Streptococcus Reference Laboratory, Colindale, for solving difficult problems in the typing of the streptococci.

We acknowledge the co-operation of Dr. E. V. Kuenssberg in allowing the studies to be conducted in the group practice. To his partners Drs. G. McNaughtan, A. A. Robertson, and A. R. Laurence, who so willingly took part in the research, we also record our appreciation. We also thank Drs. R. H. A. Swain and M. A. J. Moffet for virological advice.

\section{References}

Banatvala, J. E., Anderson, T. B., and Reiss, B. B. (1965). Fournal of Hygiene, 63,155

Bishop, J. M., Peden, A. S., Prankerd, J. A. J., and Cawley, R. H. (1952). Lancet, 1, 1183

Boycott, J. A. (1966). Lancet, 1, 706.

Breese, B. B., and Disney, F. A. (1956). Pediatrics, 17, 834.

Brimblecombe, F. S. W., Cruickshank, R., Masters, P. L., and Reid, D. D. (1958). British Medical fournal, 1, 119 .

Brumfitt, W., O'Grady, F., and Slater, J. D. H. (1959). Lancet, 2, 419.

Coburn, A. F., and Pauli, R. (1941). Fournal of Experimental Medicine, 73,551

Coburn, A. F., and Young, D. C. (1949). The Epidemiology of Haemolytic Streptococcus. Baltimore, Williams and Wilkins.

Commission on Acute Respiratory Diseases (1944). Fournal of The American Medical Association, 125, 1163.

Commission on Acute Respiratory Diseases (1945). American fournal of Public Health, 35, 675.

Commission on Acute Respiratory Diseases (1947). Fournal of The American Medical Association, 133, 588.

Cornfeld, D., Werner, G., Weaver, R., Bellows, M. T., and Hubbard, J. P. (1958). Annals of Internal Medicine, 49, 1305.

Dingle, J. H., et al. (1953). American fournal of Hygiene, 58, 16.

Esmann, V. (1959). Acta Medica Scandinavica, 163, 265.

Evans, A. S., and Dick, E. C. (1964). Fournal of The American Medical Association, 190, 699.

Glezen, W. P., Clyde, W. A., jun., Senior, R. J., Sheaffer, C. I., and Denny, F. W. (1967). Fournal of The American Medical Association, 202, 455.

Griffith, F. (1934). Fournal of Hygiene, 34, 542.

Grist, N. R., Ross, C. A. C., and Bell, E. J. (1966). In Diagnostic Methods in Clinical Virology. Oxford, Blackwell Scientific. Higgins, P. M., Abbott, B. A., James, P. M., Dillon, S., and MacMonagle,
P. J. (1965). British Medical fournal, 2, 156 .

Holmes, M. C., and Williams, R. E. O. (1954). Fournal of Hygiene, 52, 165.

Holmes, M. C., and Williams, R. E. O. (1958). Journal of Hygiene, 56, 43.

Lancefield, R. C. (1933). Fournal of Experimental Medicine, 57, 571 .

Landsman, J. B., Grist, N. R., Black, R., McFarlane, D., and Blair, W. (1951). British Medical fournal, 1, 326.

Masters, P. L., Brumfitt, W., Mendez, R. L., and Likar, M. (1958). British Medical fournal, 1, 1200 .

Maxted, W. R. (1953). Fournal of Clinical Pathology, 6, 224.

Medical Research Council (1965). British Medical fournal, 2, 319.

Mitchell, E. S. (1962). Fournal of Clinical Pathology, 15, 231.

Moffett, H. L., Cramblett, H. G., and Black, J. P. (1964). Pediatrics, 33, 5.

Mozziconacci, P., et al. (1961). Acta Paediatrica Scandinavica, 50, 33.

Parker, M. T. (1967). Bulletin of the World Health Organization, 37, 513.

Rammelkamp, C. H., Denny, F. W., and Wannamaker, L. W. (1952). In Rheumatic Fever, p. 72 University of Minnesota Press.

Siegel, A. C., Johnson, E. E., and Stollerman, G. H. (1961). New England Fournal of Medicine, 265, 559

Swift, H. F., Wilson, A. T., and Lancefield, R. C. (1943). Fournal of Experimental Medicine, $\mathbf{7 8}, 127$.

Valkenburg, H. A., Goslings, W. R. O., Bots, A. W., de Moor, C. E., and Lorrier, J. C. (1963). New England fournal of Medicine, 268, 694.

Vogel, J., and Shelokov, A. (1957). Science, 126, 358

Williams, R. E. O. (1958). Bulletin of the World Health Organization, 19, 153.

Zanen, H. C., Ganor, S., and Van Toorn, M. J. (1959). American fournal of Hygiene, 69, 265. 